\title{
In Silico Approach for the Bioremediation of Toxic Pollutants
}

\author{
Fazlurrahman Khan, Mohammad Sajid and Swaranjit Singh Cameotra*
}

Environmental Biotechnology and Microbial Biochemistry Laboratory, Institute of Microbial Technology, Sector 39-A, Chandigarh-160036, India

\begin{abstract}
Microbial degradation is considered as one of the environment friendly and cost-effective method for restoration of ecological niches contaminated with chemical pollutants. Thus before the application of microbial system for the degradation of any newly released pollutant in the environment, there is need to in silico study for predicting the possible degradation pathways by using various computational tools. There are large number of databases and computer programs available to perform the computational analysis for assisting the development and implementation of microbial bioremediation. The present review provides a comprehensive account of these databases, software, their respective work methodologies and potential application for the bioremediation. The information collected for the above study from different in silico resources for assisting the environmental degradation studies is discussed.
\end{abstract}

Keywords: Bioremediation; Database; Pollutant; Metabolic network; Bioinformatics

\section{Introduction}

Studies pertaining to re-establishment of polluted ecological niches have led to a generalized acceptance of microbial potential as environment friendly and cost effective measure by their decontamination of pollutant [1-5]. The enrichment of cultures have been proposed as one of the most potent approaches to restore the sites contaminated with pollutants, however, it has been considered as one of the demanding challenge for a long time uses [6,7]. Even though, isolation of culturable microbial strains is also one of the most important bottle-neck for the successful biodegradation [5]. Subsequently, other limitations (chemical complexity of the target pollutant, transformation of pollutant substrate into more toxic intermediates) are known to inhibit the speedy progress of the microbial bioremediation projects [8]. In the recent past, the microbial degradation studies have been pursued with a system biology approach, wherein the degradation studies are devised on the past experiences and information obtained with earlier studies [9-12]. This has resulted in a very strong need for the maintenance and easy access to this information. Consequently, there is a need for computational programs that can utilize all the available information regarding bioremediation. Thus use of various computational programmes, software, tools and database, a lot of things can be subjected to prediction approaches with the eventual objective of developing an applicable bioremediation technology. Conventionally, bioremediation studies have depended upon isolation of degradative microbial strain from the contaminated habitat $[5,6]$. Further the application of isolated strain for bioremediation in the field principally depends upon the environmental limiting factor [13]. Hence, it is necessary to implement bioremediation process in natural environmental conditions where microorganism faces the different challenges impose by various abiotic and biotic factors [1416]. However, the efficiency of the degradation process under different mechanism affected by these factors [13]. Thus, to understand the mechanism of degradation several studies has been designed to investigate the effect of all environmental factor(s) [17,18]. To study the biodegradation from lab to field, there should be ecological sustainability of the degradative strain in the field study. Thus, before going to ex situ and in situ bioremediation of any pollutants there is need to develop in silico method for the study of degradation. The present review article describes the collection of all databases, tools and softwares which helps in the in silico analysis/prediction of toxicity of any chemical along with elucidation of feasible microbial degradation pathways.

\section{In silico toxicity of the compounds}

For environmental cleanup of the toxic compounds by microorganisms many technologies have been developed, but without the knowledge of the toxicity level of the compounds it cannot be fully successful as toxicity affects the survival of the degradative strains [19]. Thus before making many efforts in development of in silico bioremediation technology of any chemicals there is also need to predict its toxicity levels by in silico approaches. Predicting toxicity of a compound by in silico toxicological methods is a developing field with great potential. More than 70 million chemicals were identified till 29 May 2013 (CAS) [20]. Exposures of these toxic chemicals e.g., pesticides, products of chemical industries like cosmetics and drugs etc. leads to various health effects [21]. Several in silico procedures have been developed and rooted by pharmaceutical industry to understand the pharmacodynamic, pharmacokinetic and toxicological profile of a compound [22]. Tables 1 and 2 summarises various databases, methods, homology models, pharmacophores and several other molecular modelling approaches for determining the toxicity of any chemical. Although there are many data bases developed about toxicity of the compounds [23], toxicity value hierarchy from Environmental Protection Agency's (EPA), and toxicity assay method [24-26]. However, various industries are synthesizing new chemicals more rapidly than academic research and the norms lay down by the regulatory agencies. The quantitative structure-activity relationships (QSARs) are the one such in silico method for determining the quantitative structure-activity relationship model, which is based on

${ }^{*}$ Corresponding author: Swaranjit Singh Cameotra, Environmental Biotechnology and Microbial Biochemistry Laboratory, Institute of Microbial Technology, Sector 39-A, Chandigarh-160036, India, Tel: +91-6665223/224; Fax: +91-172-2690632; E-mail: ssc@imtech.res.in

Received October 07, 2013; Accepted November 22, 2013; Published November 29,2013

Citation: Khan F, Sajid M, Cameotra SS (2013) In Silico Approach for the Bioremediation of Toxic Pollutants. J Pet Environ Biotechnol 4: 161. doi:10.4172/2157-7463.1000161

Copyright: ( 2013 Khan F, et al. This is an open-access article distributed under the terms of the Creative Commons Attribution License, which permits unrestricted use, distribution, and reproduction in any medium, provided the original author and source are credited. 
Citation: Khan F, Sajid M, Cameotra SS (2013) In Silico Approach for the Bioremediation of Toxic Pollutants. J Pet Environ Biotechnol 4: 161. doi:10.4172/2157-7463.1000161

Page 2 of 7

\begin{tabular}{|c|c|c|c|}
\hline S.No & Name of Programme & URLCode & Properties/Reference \\
\hline 1. & Derek (Lhasa Ltd) & http://www.Ihasalimited.org/ & $\begin{array}{l}\text { Lhasa Limited specialises in the development of in silico prediction and database systems for } \\
\text { use in metabolism, toxicology and related sciences. }\end{array}$ \\
\hline 2. & HazardExpert (CompuDrug) & http://www.compudrug.com/ & CompuDrug is software tool to estimate toxicity of an organic compound in higher animals. \\
\hline 3. & ACD/Tox Suite (ToxBoxes) & $\begin{array}{l}\text { http://www.acdlabs.com/products/ } \\
\text { pcadmet/tox/tox/ }\end{array}$ & $\begin{array}{l}\text { ACD/Tox Suite is a collection of software modules that predict probabilities for basic toxicity } \\
\text { endpoints. }\end{array}$ \\
\hline 4. & ADMET Predictor & $\begin{array}{l}\text { http://www.simulations-plus.com/ } \\
\text { Products.aspx?plD=13 }\end{array}$ & $\begin{array}{l}\text { ADMET acronym indicates all the parameters associated with absorption, metabolism, } \\
\text { distribution, elimination, and toxicity of chemical in the human tissue. }\end{array}$ \\
\hline 5. & OncoLogic (USEPA) & $\begin{array}{l}\text { http://www.epa.gov/oppt/sf/pubs/ } \\
\text { oncologic.htm }\end{array}$ & $\begin{array}{l}\text { OncoLogic }{ }^{\mathrm{TM}} \text { is a computer program that evaluates the likelihood that a chemical may cause } \\
\text { cancer. }\end{array}$ \\
\hline 6. & Toxtree (JRC) & $\begin{array}{l}\text { http://ihcp.jrc.ec.europa.eu/our_labs/ } \\
\text { predictive_toxicology/qsar_tools/ } \\
\text { toxtree }\end{array}$ & $\begin{array}{l}\text { Toxtree open-source application that classifies toxic chemicals into various categories and } \\
\text { predicts their toxic effect by using decision tree approaches. }\end{array}$ \\
\hline 7. & MolCode Toolbox & http://www.molcode.com & $\begin{array}{l}\text { Molcode Toolboxe applies to simulate various experimentally unknown properties of } \\
\text { compounds including physical, chemical, biological, ADME-Tox, ecological pathways/ eco- } \\
\text { toxicity and adverse drug effects. }\end{array}$ \\
\hline 8. & TerraQSAR $^{\text {TM }}$ & http://www.terrabase-inc.com/ & $\begin{array}{l}\text { TerraQSAR }{ }^{\mathrm{TM}} \text { computation programs are designed for the quick and reliable estimation of } \\
\text { biological effects and physico-chemical properties of organic compounds. }\end{array}$ \\
\hline 9. & $\begin{array}{l}\text { Toxicity Estimation software } \\
\text { tool (T.E.S.T) }\end{array}$ & $\begin{array}{l}\text { http://www.epa.gov/nrmrl/std/qsar/ } \\
\text { qsar.html }\end{array}$ & $\begin{array}{l}\text { TEST will enable users to easily estimate acute toxicity using several different QSAR } \\
\text { methodologies including a hierarchical method, FDA method, Single-model method, Group } \\
\text { contribution method, Nearest neighbour method, Random forest method, multiple linear } \\
\text { regressions, and Consensus method. }\end{array}$ \\
\hline 10. & ORCHESTRA & http://www.orchestra-qsar.eu & $\begin{array}{l}\text { A project funded by EC to disseminate recent research on computer-based methods to } \\
\text { evaluate the toxicity of hazardous chemicals [64]. }\end{array}$ \\
\hline 11. & VirtualToxLa & http://www.biograf.ch & $\begin{array}{l}\text { It is an in silico tool for predicting the toxicity of drugs, chemicals, and natural products. It } \\
\text { simulates and quantifies their relations toward a series of proteins known to trigger adverse } \\
\text { effects using automated, flexible docking combined with multidimensional QSAR [65]. }\end{array}$ \\
\hline
\end{tabular}

Table 1: Software tools for toxicity prediction.

\begin{tabular}{|c|c|c|c|}
\hline S.No. & Name of Database & URLCode & Properties/Reference \\
\hline 1. & Acutoxbase & https://acubase.amwaw.edu.pl & $\begin{array}{l}\text { Acutebase has been developed to manage all information relevant to the EU integrated } \\
\text { project 'ACuteTox'. It provides in vitro testing approach for predicting human toxicity of a } \\
\text { compound [66]. }\end{array}$ \\
\hline 2. & ChemIDplus & http://chem.sis.nlm.nih.gov/chemidplus/ & $\begin{array}{l}\text { ChemIDplus is web-based search application which allows opening structure and } \\
\text { nomenclature authority files of chemical substances cited in National Library of Medicine } \\
\text { (NLM) databases including the TOXNET }{ }^{\circledR} \text { system. }\end{array}$ \\
\hline 3. & $\begin{array}{l}\text { Chemical Effects in } \\
\text { Biological Systems (CEBS) }\end{array}$ & $\begin{array}{l}\text { http://www.niehs.nih.gov/research/ } \\
\text { resources/databases/cebs/index.cfm }\end{array}$ & $\begin{array}{l}\text { CEBS is applying to view data in the form of biology and study design and permit data } \\
\text { integration across studies. }\end{array}$ \\
\hline 4. & Terra-Base & $\begin{array}{l}\text { http://www.terrabase } \\
\text {-inc.com/ }\end{array}$ & $\begin{array}{l}\text { TerraTox }{ }^{\mathrm{TM}} \text { databases provide for the quick search of compounds with structure/ } \\
\text { fragment-specific biological effects and properties. }\end{array}$ \\
\hline 5. & GENE-TOX & $\begin{array}{l}\text { http://toxnet.nlm.nih.gov/cgi-bin/sis/ } \\
\text { htmlgen?GENETOX }\end{array}$ & $\begin{array}{l}\text { Databank developed by the Environmental Protection Agency (EPA) through genetic } \\
\text { toxicology. }\end{array}$ \\
\hline 6. & $\begin{array}{l}\text { Hazardous Substances } \\
\text { Data Bank }\end{array}$ & $\begin{array}{l}\text { http://toxnet.nlm.nih.gov/cgi-bin/sis/ } \\
\text { htmlgen?HSDB }\end{array}$ & $\begin{array}{l}\text { Hazardous substance data Bank is toxicology database on National library of Medicine. } \\
\text { It has information regarding exposure routes, industrial hygiene, emergency handling } \\
\text { procedures, environmental fate and regulatory details. }\end{array}$ \\
\hline 7. & SuperToxic & $\begin{array}{l}\text { http://bioinformatics.charite.de/ } \\
\text { supertoxic/index.php?site=home }\end{array}$ & $\begin{array}{l}\text { Recently, this database has information of approximately } 60,000 \text { compounds which are } \\
\text { classified according to their toxicological profiles. }\end{array}$ \\
\hline 8. & $\begin{array}{l}\text { Aggregated Computational } \\
\text { Toxicology Resource) }\end{array}$ & $\begin{array}{l}\text { http://actor.epa.gov/actor/faces/ } \\
\text { ACToRHome.jsp }\end{array}$ & $\begin{array}{l}\text { ACToR is openly access chemical toxicity database and can be used to discover potential } \\
\text { chemical hazards to human health and the environment. }\end{array}$ \\
\hline 9. & $\begin{array}{l}\text { Comparative } \\
\text { Toxicogenomics Database }\end{array}$ & $\begin{array}{l}\text { http://toxnet.nlm.nih.gov/cgi-bin/sis/ } \\
\text { htmlgen?CTD }\end{array}$ & $\begin{array}{l}\text { CTD }{ }^{\mathrm{TM}} \text {-elucidates human toxicity of a compound and its molecular mechanisms by which } \\
\text { environmental chemicals acts. }\end{array}$ \\
\hline 10. & $\begin{array}{l}\text { Carcinogenic Potency } \\
\text { Database }\end{array}$ & $\begin{array}{l}\text { http://toxnet.nlm.nih.gov/cgi-bin/sis/ } \\
\text { htmlgen?CPDB.htm }\end{array}$ & $\begin{array}{l}\text { CPD provides standardized analyses of chronic, long-term animal cancer tests and } \\
\text { reported in the general published literature or by the National Cancer Institute and the } \\
\text { National Toxicology Program. }\end{array}$ \\
\hline
\end{tabular}

Table 2: Databases containing toxicity information

experimental or calculated data [27] (Figure 1). The toxicity of allelechemical like pesticides can be also predicted by applying combination of methods such as 3D-QSAR, docking, Local Binding Energy (LBE) and GRID [28]. Further, OSIRIS property explorer is another in silico method for assessing the toxicity of any chemical compound. Discovery of newer drug may also bring health hazards. The information regarding toxicological profile of known toxins will make a basis to assign the toxicity of unknown compound. The Structural Bioinformatics Group, Institute of Molecular Biology and Bioinformatics, Charite (Cbf), Berlin, Germany created a SuperToxic database containing information of various toxic compounds $(\sim 60,000)$.

\section{Prediction of environmental destiny of toxic compounds}

Biodegradation of toxic chemicals is most important parameter influencing whether compound will be biodegraded and, if so, will the biodegradation proceed slowly or quickly. To study the biodegradability in silico there are several softwares and databases available (Table 3). Among softwares most important one is BESS (Biodegradability Evaluation and Simulation System) [29]. The prediction of biodegradation of a compound can be made possible by using BESS software based on structural description of the compound and the existing environmental condition. BESS uses promising enzymatic 
Citation: Khan F, Sajid M, Cameotra SS (2013) In Silico Approach for the Bioremediation of Toxic Pollutants. J Pet Environ Biotechnol 4: 161. doi:10.4172/2157-7463.1000161

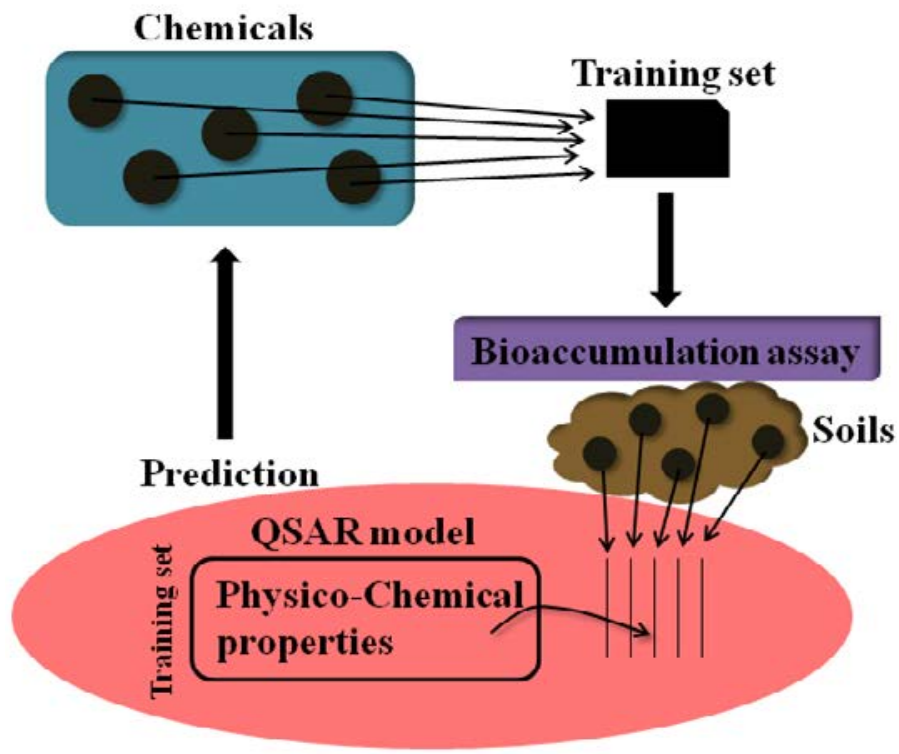

Figure 1: QSAR model for bioremediation.

\begin{tabular}{|c|c|c|c|}
\hline S.No. & URL Code & Properties & References \\
\hline 1. & $\begin{array}{l}\text { http://www.labmed.umn.edu/umbbd/ index. } \\
\text { html }\end{array}$ & Prediction of biodegradation pathway & [67] \\
\hline 2. & $\begin{array}{l}\text { http://www.labmed.umn.edu/umbbd/ } \\
\text { predictbt/ }\end{array}$ & $\begin{array}{l}\text { Predicting Biotransformation build on existing bio degradation information contained in the UM- } \\
\text { BBD. }\end{array}$ & [68] \\
\hline 3. & http://umbbd.ahc.umn.edu/index.html & UM-BBD: University of Minnesota Biocatalysis/Biodegradation Database. & [69] \\
\hline 4. & http://umbbd.msi.umn.edu/predict/ & $\begin{array}{l}\text { UM-PPS: predicts microbial catabolic reactions using substructure searching, a rule-base and } \\
\text { atom-to-atom mapping. }\end{array}$ & [70] \\
\hline 5. & http://www.genome.ad.jp/kegg/kegg2.html & KEGG: Kyoto Encyclopaedia of Genes and Genomes. & [71] \\
\hline 6. & $\begin{array}{l}\text { http://www.expasy.org/cgi-bin/search- } \\
\text { biochem-index }\end{array}$ & Boehringer Mannheim Biochemical Pathways on the ExPASy server, Switzerland. & [72] \\
\hline 7. & http://emp.mcs.anl.gov/ & Enzyme and Metabolic Pathway (EMP) Database at Argonne National Laboratories. & [73] \\
\hline 8. & http://www.issx.org/ & International society for study of Xenobiotics. & \\
\hline 9. & http://biocyc.org/ & Biocyc: Knowledge Library of Pathway/ Genome Databases. & [74] \\
\hline 10. & http://www.ncgr.org/pathdb/ & Path DB: Metabolic Pathways Database at NCGR. & [75] \\
\hline 11. & $\begin{array}{l}\text { http://www.tcd.ie/Biochemistry/IUBMB- } \\
\text { Nicholson/ }\end{array}$ & Metabolic Pathway Minimaps at Trinity College, Dublin, Ireland. & [76] \\
\hline 12. & $\begin{array}{l}\text { http://www.daylight.com/smiles/f_smiles. } \\
\text { html }\end{array}$ & SMILES is a system for coding chemical compounds as linear strings of ASCII characters. & [77] \\
\hline 13. & http://biorad.igib.res.in & BioRad Base is a database for bioremediation of radioactive waste. & [78] \\
\hline 14. & http://bsd.cme.msu.edu & Biodegradative Strain Database & [47] \\
\hline 15. & $\begin{array}{l}\text { http://www.epa.gov/opptintr/exposure/pubs/ } \\
\text { episuite.htm }\end{array}$ & $\begin{array}{l}\text { A Windows }{ }^{\circledR} \text {-based, EPI (Estimation Programs Interface) Suite }{ }^{\mathrm{TM}} \text { provides physical/ chemical } \\
\text { properties and environmental fate. }\end{array}$ & [79] \\
\hline
\end{tabular}

Table 3: Programme, databases and web resources containing biodegradability information.

reactions that are hierarchically organised according to knowledge of microbial physiology and ecology. Such type of prediction reduces the potential large number of enzymatic conversion which is most likely to provide anabolic intermediates or energy to micro-organisms (Figure 2a). Biochemical Network Integrated Computational explorer (BNICE) is also known for the prediction of possible microbial degradation pathways (14). It involves rules of enzyme classification system and predicts thermodynamically favoured reactions rather than using microbial physiological and ecological conditions (Figure $2 \mathrm{~b}$ ). The multi computer automated structure evaluation/ (MultiCASE/META) system combines a group-contribution model and an expert system to simulate aerobic biodegradation pathways [30]. MultiCASE approach has been also used to model anaerobic aquatic biodegradation rates [31]. Mineralization of organic compound is a significant factor when considering their fate in the environment. A model was developed and integrated into an expert software system named CATABOL which is a knowledge based expert system [32]. It can simulate the likelihood of biodegradation of organic compounds directly from their structure. However, this probabilistic model can also be useful in determining the probabilities for overall Biochemical Oxygen Demand (BOD) and extent of $\mathrm{CO}_{2}$ production in bioremediation process [32,33]. Fate of a specific chemical spilled in a given site and even show interventions aimed at accelerating the process can be described by MetaRouter system [34]. The MetaRouter allows visualization through a web interface of all probable pathways that a large number of intractable compounds can take through known steps of all the reactions taken from the UM-BBD. The system searches in the database for all possible combination of enzymes (and wherever available, their cognate 
Citation: Khan F, Sajid M, Cameotra SS (2013) In Silico Approach for the Bioremediation of Toxic Pollutants. J Pet Environ Biotechnol 4: 161. doi:10.4172/2157-7463.1000161

Page 4 of 7

(a)

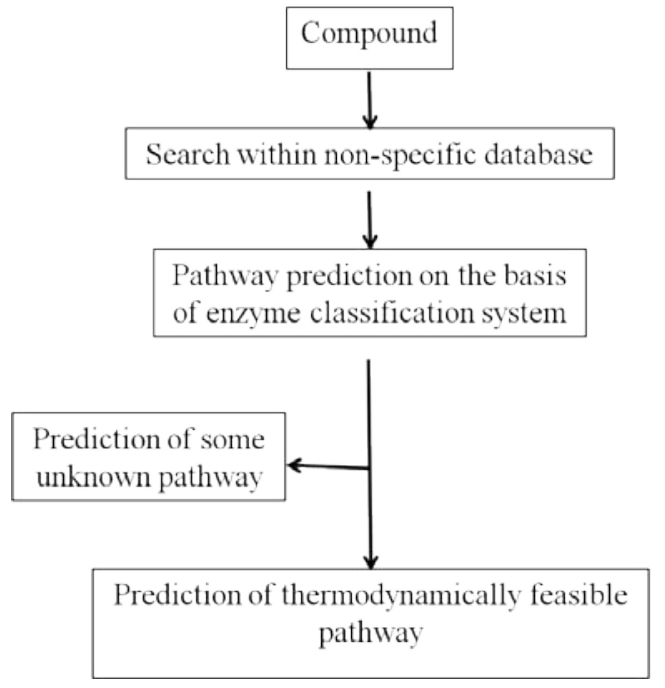

(b)

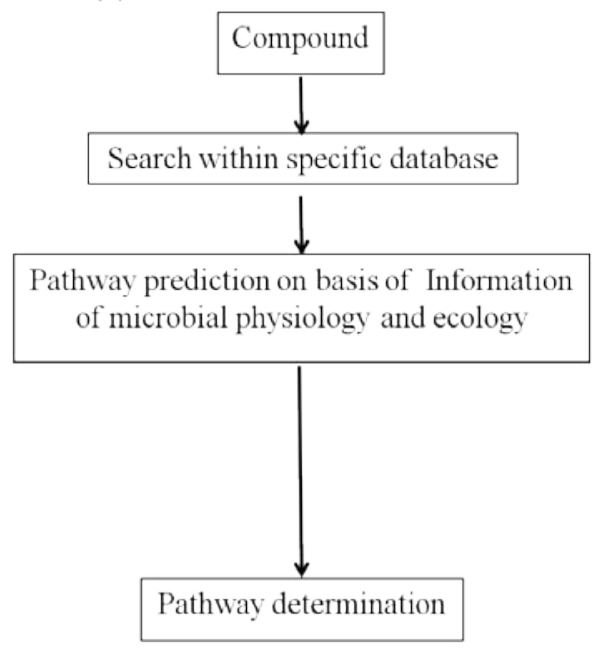

Figure 2: Comparison between pathway prediction rules between BNICE (2a) and BESS (2b).

genes) required to convert a certain substrate into their metabolic intermediates or into any other products. Through MetaRouter system a virtual pathways having meshwork of genes/enzymes can be predicted which come from different bacteria, sometimes having very different lifestyles (for instance, aerobic and anaerobic). Nevertheless, such combinations may not exist or may have not been exposed yet in nature, these cross pathways reflect probable processes that can occur at different stages and locations by divergent microorganisms. The MetaRouter system does not give information regarding kinetics or thermodynamics of the proposed pathways, although it can certainly guide metabolic engineering attempts. Although MetaRouter describes only biodegradation information for a compound and gives a picture of how given chemicals could be degraded if passed through the complex metabolism of a complex community rather than how they could be metabolized by one specialist strain [34]. Metabolic Knowledgebase (MKB) uses ontology to formalize metabolic data and apply large flexible and scalable metabolic knowledgebase to capture several levels of chemical or biological information. It develops inference tools to support complex metabolic queries to semantically integrate data from chemical structures to complete pathways; incorporate data from public domain sources. Biocatalysis Classification Scheme (BCS) uses MKB to identify subset of biocatalytic function based on pathway of interest and to find relevant compounds and infer their sub structural features. Biocatalysis Assignment Tool (BAT) uses MKB to identify relevant sets of proteins and their biocatalytic functions. It also identifies conserved features among proteins and establishes correlation between function and conserved features. Metabolic Pathway Synthesis (MPS) provides information regarding predicting enzymatic activity from the cellular environment and helps to classify pathways with respect to cellular parameters and to obtain information about metabolic pathway and its regulation. It uses $\mathrm{BCS} / \mathrm{MKB}$ to find out the possible transformation from native compound to intermediates. In case of database KEGG (Kyoto Encyclopedia of Genes and Genomes), commonly used resource provides information on genes and metabolic pathways in a wide range of species [35]. KEGG consists of three databases: PATHWAY provides network of interacting molecules, GENES contains catalogs of all full and partial genome sequence and LIGAND for the collection of chemical compounds in the cell, enzyme molecules and enzymatic reactions [36].

\section{Influence of environmental factors on biodegradation}

Earlier studies of bioremediation trials were not performed under natural environmental conditions. Therefore, the impact of environmental factors on the bioremediation process was never expected. However, after the investigation of in situ bioremediation approaches now it is feasible to understand the bioremediation process is influenced significantly by environmental factors such as the physiological and chemical ambience of the contaminated environment, bioavailability of nutrients, concentration and properties of cocontaminants, level of contamination, community organization of the indigenous microbial communities [13,37-40]. Various abiotic and biotic factors play important role in bioremediation. Their dynamic interactions occur in concrete abiotic conditions which are defined by physico-chemical conditions like $\mathrm{O}_{2}$ supply, electron transport, water, temperature, $\mathrm{pH}$, salt concentration, many of which [41-43]. The above environmental factors determine the dynamic of endogenous microbial community structures along with the availability of given chemical and energy source [41].

\section{Ecological consequences on the biodegradative strains}

Knowledge of indigenous microflora is required which may or may not affect the degradation of toxic compounds by test microorganism [13]. In situ bioremediation is directly or indirectly affected by the indigenous micro flora, thus it is most important to evaluate the ecological consequences on the biodegradative strains [13,41]. There are several non related phenomenons to study these ecological consequences. However, for the development of bioremediation technology, it is required to analyze the effect on indigenous microbial community structure by the bioremediation process in a particular ecological conditions [41,42,44-46]. Biodegradative Strain Database (BSD) provides information of degradative bacteria and hazardous chemicals degraded by these bacteria [47]. It also includes corresponding literature citation, relevant patents and link to additional web based biological and chemical data. The BSD is being developed within the phylogenetic framework of the Ribosomal Database Project 
Citation: Khan F, Sajid M, Cameotra SS (2013) In Silico Approach for the Bioremediation of Toxic Pollutants. J Pet Environ Biotechnol 4: 161. doi:10.4172/2157-7463.1000161

II to provide a biological complement to the chemical and degradative pathway [47]. Ecological Structure Activity Relationships (ECOSAR) is a foretelling system providing information for aquatic toxicity of a compound [48]. The program estimates a chemicals acute toxicity and chronic toxicity to aquatic organisms by using computerized Structure Activity Relationships (SARs).

\section{Discussion}

As a result of worldwide extensive application of pesticides, it may get released into different environmental compartment (e.g. soil, sediment and water bodies) through waste streams and causing threat to the various life forms [3]. Thus public concern has been prompted to develop robust technology for the eradication of pesticides and restoration of environmental health. There are two ways for the decontamination of pesticides from the environment; one is nonbiological (e.g. incineration, land filling, hydrolysis, photolysis, chemical lysis and thermal decomposition) and the second is biological means $[2,3,49,50]$. Mostly the microbial transformation/degradation of the pesticides/ or chemical is considered as one of the most effective, ecofriendly and technologically challenging approaches for the bioremediation of toxic pollutants from the different environmental compartment $[3,4,51,52]$. The bioremediation database provides by University of Minnesota provides most comprehensive platform for nearly all the bioremediation pathway and helps in developing various prediction programmes using these databases [53]. Pathway prediction system (PPS) predicts possible bioremediation pathway for xenobiotics using biotransformation parameters provided by UM-BBD database as well as scientific literature [54]. Other programmes similar to PPS are METEOR, MetabolExpert, DEREK, StAR, CATABOL system, MetaRouter and MultiCASE/META [32,34,55-58]. To establish strain designation in prediction of bioremediation within phylogenetic perspective, Biodegradative Strain Database (BSD) was developed by integrating metabolic data of UM-BBD and phylogenetic data of Ribosome Database project (RPD-II) [47]. Till now dogma of the biodegradation is one strain degrades one pollutant, but information available in literature of bioremediation lack essential aspect of natural scenarios, like interchange of gene between bacteria or their metabolic network co-operation [51,59,60]. It has also been known a single microbe exhibit metabolically versatile in nature due to the presence of large size of genome and plasmid containing large number of metabolic genes, resulting in expansion of the multiple metabolic pathways [43]. However, insufficient biological information regarding the regulation of growth and metabolism in various microbial communities restricts development in the site-specific mineralization process. Similarly, the bioremediation of xenobiotic compounds either ex situ or in situ by pure isolates does not represent an actual behaviour of the microorganisms; however, it depends on cooperative metabolic activities of mixed microbial population [61-63]. Under these conditions biodegradative potential of all microbes can be crossed with the all known compounds and in silico bioremediation helps to predict the destiny of a compound whether partially or fully degraded to non toxic compounds. Bioinformatics based search will facilitate and speed up the analysis of microbial degradation of hazardous compounds. In situ bioremediation can be applied in a number of action modes including aerobic, anaerobic, anoxic (nitrate respiration) and cometabolic. Bioinformatics have huge amount of data collected from various resources such as chemical structure and reactivity properties of compounds; protein sequence, structure and function; comparative genome analysis; phylogenetic analysis; environmental biotechnology. These informations will collectively provide a bigger picture regarding degradation of a compound in the environment (Figure 3 ). The above summarized computational database, software and tools and their collective integration will help to determine the environmental fate of any compounds more precisely and accurately. After predicting the more accurate the environmental fate of any compound by computational approaches, future work will be carried out to validate

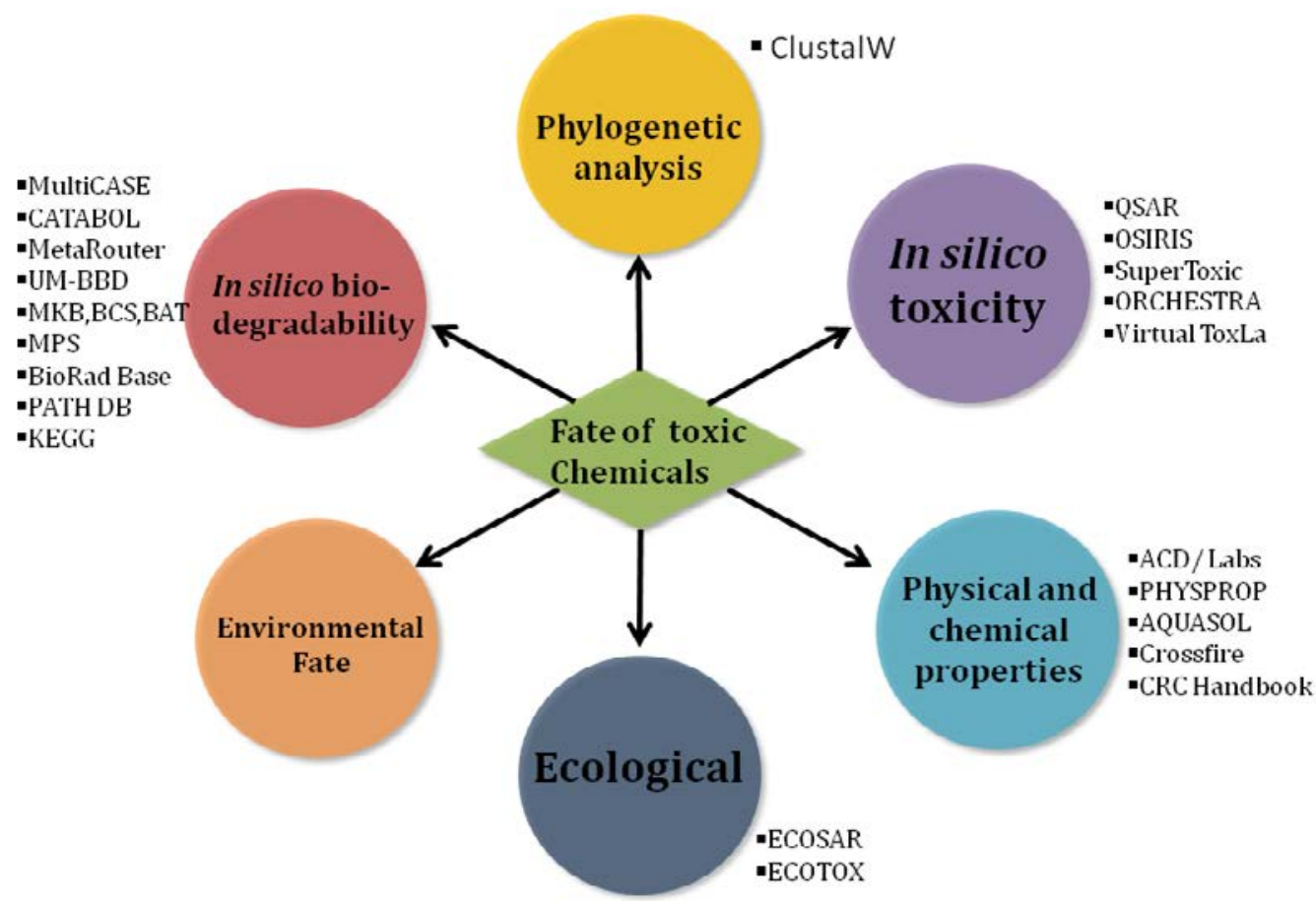

Figure 3: Schematic representations of prediction softwares and databases involve in destiny of a toxic compounds. 
Citation: Khan F, Sajid M, Cameotra SS (2013) In Silico Approach for the Bioremediation of Toxic Pollutants. J Pet Environ Biotechnol 4: 161. doi:10.4172/2157-7463.1000161

the complete fate of the compound by single isolate as well as by mixed microbial consortium. The pathway predicting software will also help in minimizing the number of possible combination for the development of microbial consortia.

\section{Acknowledgements}

FK thanks DBT for the Research Associate ship and MS acknowledge his research fellowship from UGC, India. This is the IMTECH communication no 0123/2013.

\section{References}

1. Lovley DR (2003) Cleaning up with genomics: applying molecular biology to bioremediation. Nat Rev Microbiol 1: 35-44.

2. Paul D, Pandey G, Pandey J, Jain RK (2005) Accessing microbial diversity for bioremediation and environmental restoration. Trends Biotechnol 23: 135-142.

3. Khan F, Pal D, Vikram S, Cameotra SS (2013) Metabolism of 2-chloro-4nitroaniline via novel aerobic degradation pathway by Rhodococcus $\mathrm{sp}$. strain MB-P1. PLoS One 8: e62178.

4. Khan F, Vyas B, Pal D, Cameotra SS (2013) Aerobic Degradation of N-Methyl4-Nitroaniline (MNA) by Pseudomonas sp. Strain FK357 Isolated from Soil. PLoS One 8: e75046.

5. Fazlurrahman, Batra M, Pandey J, Suri CR, Jain RK (2009) Isolation and characterization of an atrazine-degrading Rhodococcus sp. strain MB-P1 from contaminated soil. Lett Appl Microbiol 49: 721-729.

6. Khan F, Pandey J, Vikram S, Pal D, Cameotra SS (2013) Aerobic degradation of 4-nitroaniline (4-NA) via novel degradation intermediates by Rhodococcus sp. strain FK48. J Hazard Mater 254-255: 72-8.

7. Mohn WW, Tiedje JM (1992) Microbial reductive dehalogenation. Microbiol Rev 56: 482-507.

8. Boopathy R (2000) Factors limiting bioremediation technologies. Bioresource Technol 74: 63-67.

9. Finley SD, Broadbelt LJ, Hatzimanikatis V (2010) In silico feasibility of novel biodegradation pathways for 1,2,4-trichlorobenzene. BMC Syst Biol 4: 7 .

10. Hou BK, Wackett LP, Ellis LB (2003) Microbial pathway prediction: a functional group approach. J Chem Inf Comput Sci 43: 1051-1057.

11. Ellis LB, Roe D, Wackett LP (2006) The University of Minnesota Biocatalysis/ Biodegradation Database: the first decade. Nucleic Acids Res 34: D517-521.

12. Wackett LP, Ellis LB (1999) Predicting biodegradation. Environ Microbiol 1: 119-124.

13. Pandey J, Chauhan A, Jain RK (2009) Integrative approaches for assessing the ecological sustainability of in situ bioremediation. FEMS Microbiol Rev 33: 324-375

14. Ward DM, Brock TD (1976) Environmental factors influencing the rate of hydrocarbon oxidation in temperate lakes. Appl Environ Microbiol 31: 764-772.

15. Dinkla IJ, Gabor EM, Janssen DB (2001) Effects of iron limitation on the degradation of toluene by Pseudomonas strains carrying the tol (pWWO) plasmid. Appl Environ Microbiol 67: 3406-3412.

16. Kim HJ, Graham DW (2003) Effects of oxygen and nitrogen conditions on the transformation kinetics of 1,2-dichloroethenes by Methylosinus trichosporium OB3b and its sMMOC mutant. Biodegradation 14: 407-414.

17. Hoyle BL, Scow KM, Fogg GE, Darby JL (1995) Effect of carbon:nitrogen ratio on kinetics of phenol biodegradation by Acinetobacter johnsonii in saturated sand. Biodegradation 6: 283-293.

18. Lovanh N, Hunt CS, Alvarez PJ (2002) Effect of ethanol on BTEX biodegradation kinetics: aerobic continuous culture experiments. Water Res 36: 3739-3746.

19. Copley SD (2009) Evolution of efficient pathways for degradation of anthropogenic chemicals. Nat Chem Biol 5: 559-566.

20. 2013 CAS Spring Meeting Vancouver, Canada.

21. Rider CV, Carlin DJ, Devito MJ, Thompson CL, Walker NJ (2012) Mixtures research at NIEHS: An evolving program. Toxicology .

22. Ekins S, Mestres J, Testa B (2007) In silico pharmacology for drug discovery: applications to targets and beyond. Br J Pharmacol 152: 21-37.
23. Schmidt U, Struck S, Gruening B, Hossbach J, Jaeger IS, et al. (2009) SuperToxic: a comprehensive database of toxic compounds. Nucleic Acids Res 37: D295-299.

24. Ohga T, Masduki A, Kato J, Ohtake H (1993) Chemotaxis away from thiocyanic and isothiocyanic esters in Pseudomonas aeruginosa. FEMS Microbiol Lett 113: 63-66.

25. Sager BM, Sekelsky JJ, Matsumura P, Adler J (1988) Use of a computer to assay motility in bacteria. Anal Biochem 173: 271-277.

26. Nikata T, Sumida K, Kato J, Ohtake H (1992) Rapid method for analyzing bacterial behavioral responses to chemical stimuli. Appl Environ Microbiol 58: 2250-2254.

27. Schultz TW, Cronin MTD, Walker JD, Aptula AO (2003) Quantitative structureactivity relationships (QSARs) in toxicology: a historical perspective. J Mo Struc-THEOCHEM 622: 1-22.

28. Fratev F, Lo Piparo E, Benfenati E, Mihaylova E (2007) Toxicity study of allelochemical-like pesticides by a combination of 3D-QSAR, docking, Local Binding Energy (LBE) and GRID approaches. SAR QSAR Environ Res 18: 675-692.

29. Williams PF (2000) BESS, A System for Predicting the Biodegradability of New Compounds. Environmental Protection Agency USA

30. Klopman G, Tu M, Talafous J (1997) META. 3. A genetic algorithm for metabolic transform priorities optimization. J Chem Inf Comput Sci 37: 329-334.

31. Rorije E, Peijnenburg WJGM, Klopman G (1998) Structural requirements for anaerobic biodegradation of organic chemicals: A fragment model analysis. Environ Toxicol Chem 17: 1943-1950.

32. Jaworska J, Dimitrov S, Nikolova N, Mekenyan O (2002) Probabilistic assessment of biodegradability based on metabolic pathways: catabol system. SAR QSAR Environ Res 13: 307-323.

33. Jaworska J, Van Genderen-Takken H, Hanstveit A, van de Plassche E, Feijte $\mathrm{T}$ (2002) Environmental risk assessment of phosphonates, used in domestic laundry and cleaning agents in The Netherlands. Chemosphere 47: 655-665.

34. Pazos F, Guijas D, Valencia A, De Lorenzo V (2005) MetaRouter: bioinformatics for bioremediation. Nucleic Acids Res 33: D588-592.

35. Kanehisa M, Goto S (2000) KEGG: kyoto encyclopedia of genes and genomes. Nucleic Acids Res 28: 27-30.

36. Goto S, Nishioka T, Kanehisa M (2000) LIGAND: chemical database of enzyme reactions. Nucleic Acids Res 28: 380-382.

37. Leahy JG, Colwell RR (1990) Microbial degradation of hydrocarbons in the environment. Microbiol Rev 54: 305-315.

38. Mills DK, Fitzgerald K, Litchfield CD, Gillevet PM (2003) A comparison of DNA profiling techniques for monitoring nutrient impact on microbial community composition during bioremediation of petroleum-contaminated soils. J Microbiol Methods 54: 57-74.

39. Moreels D, Bastiaens L, Ollevier F, Merckx R, Diels L, et al. (2004) Effect of in situ parameters on the enrichment process of MTBE degrading organisms. Commun Agric Appl Biol Sci 69: 3-6.

40. Coulon F, McKew BA, Osborn AM, McGenity TJ, Timmis KN (2007) Effects of temperature and biostimulation on oil-degrading microbial communities in temperate estuarine waters. Environ Microbiol 9: 177-186.

41. Katsivela E, Moore ER, Maroukli D, Strömpl C, Pieper D, et al. (2005) Bacteria community dynamics during in-situ bioremediation of petroleum waste sludge in landfarming sites. Biodegradation 16: 169-180.

42. Wenderoth DF, Rosenbrock P, Abraham WR, Pieper DH, Höfle MG (2003) Bacterial community dynamics during biostimulation and bioaugmentation experiments aiming at chlorobenzene degradation in groundwater. Microb Ecol 46: 161-176.

43. Eyers L, Smoot JC, Smoot LM, Bugli C, Urakawa H, et al. (2006) Discrimination of shifts in a soil microbial community associated with TNT-contamination using a functional ANOVA of 16S rRNA hybridized to oligonucleotide microarrays Environ Sci Technol 40: 5867-5873.

44. Röling WF, Milner MG, Jones DM, Fratepietro F, Swannell RP, et al. (2004) Bacterial community dynamics and hydrocarbon degradation during a fieldscale evaluation of bioremediation on a mudflat beach contaminated with buried oil. Appl Environ Microbiol 70: 2603-2613. 
Citation: Khan F, Sajid M, Cameotra SS (2013) In Silico Approach for the Bioremediation of Toxic Pollutants. J Pet Environ Biotechnol 4: 161. doi:10.4172/2157-7463.1000161

45. Viñas M, Sabaté J, Espuny MJ, Solanas AM (2005) Bacterial community dynamics and polycyclic aromatic hydrocarbon degradation during bioremediation of heavily creosote-contaminated soil. Appl Environ Microbio 71: 7008-7018.

46. Paul D, Pandey G, Meier C, van der Meer JR, Jain RK (2006) Bacteria community structure of a pesticide-contaminated site and assessment of changes induced in community structure during bioremediation. FEMS Microbiol Ecol 57: 116-127.

47. Urbance JW, Cole J, Saxman P, Tiedje JM (2003) BSD: the Biodegradative Strain Database. Nucleic Acids Res 31: 152-155.

48. Levet A, Bordes C, Clément Y, Mignon P, Chermette H, et al. (2013) Quantitative structure-activity relationship to predict acute fish toxicity of organic solvents. Chemosphere 93: 1094-1103.

49. Dua M, Singh A, Sethunathan N, Johri AK (2002) Biotechnology and bioremediation: successes and limitations. Appl Microbiol Biotechnol 59: 143152

50. Khan F, Prakash D, Jain R (2011) Development of an HPLC method for determination of pentachloronitrobenzene, hexachlorobenzene and their possible metabolites. BMC Chem Biol 11: 2 .

51. Khan F, Pal D, Ghosh A, Cameotra SS (2013) Degradation of 2,4-dinitroanisole (DNAN) by metabolic cooperative activity of Pseudomonas sp. strain FK357and Rhodococcus imtechensis strain RKJ300. Chemosphere 93: 2883-2888.

52. Khan F, Kumari M, Cameotra SS (2013) Biodegradation of the Allelopathic Chemical m-Tyrosine by Bacillus aquimaris SSC5 Involves the Homogentisate Central Pathway. PLoS One 8: e75928.

53. Hou BK, Ellis LB, Wackett LP (2004) Encoding microbial metabolic logic: predicting biodegradation. J Ind Microbiol Biotechnol 31: 261-272.

54. Klopman G, Zhang Z, Balthasar DM, Rosenkranz HS (1995) ComputerAutomated predictions of aerobic biodegradation of chemicals. Environ Toxico Chem 14: 395-403.

55. Klopman G, Dimayuga M, Talafous J (1994) META. 1. A program for the evaluation of metabolic transformation of chemicals. J Chem Inf Comput Sci 34: $1320-1325$

56. Greene N, Judson PN, Langowski JJ, Marchant CA (1999) Knowledge-based expert systems for toxicity and metabolism prediction: DEREK, StAR and METEOR SAR QSAR Environ Res 10: 299-314.

57. Oh M, Yamada T, Hattori M, Goto S, Kanehisa M (2007) Systematic analysis of enzyme-catalyzed reaction patterns and prediction of microbial biodegradation pathways. J Chem Inf Model 47: 1702-1712.

58. Darvas F (1987) Metabolexpert: An Expert System for Predicting Metabolism of Substances. QSAR in Environmental Toxicology - II 71-81.

59. [No authors listed] (1991) Clinical results using two new antibioticsclarithromycin and temafloxacin. Oncology (Williston Park) 5: 142, 145-146.

60. de Souza ML, Newcombe D, Alvey S, Crowley DE, Hay A, et al. (1998) Molecular basis of a bacterial consortium: interspecies catabolism of atrazine. Appl Environ Microbiol 64: 178-184.

61. Boonchan S, Britz ML, Stanley GA (2000) Degradation and mineralization of high-molecular-weight polycyclic aromatic hydrocarbons by defined fungalbacterial cocultures. Appl Environ Microbiol 66: 1007-1019.

62. Wang Z, Zhang J, Zhang Y, Hesham AL, Yang M (2006) Molecular characterization of a bacterial consortium enriched from an oilfield that degrades phenanthrene. Biotechnol Lett 28: 617-621.
63. Barreiros L, Nogales B, Manaia CM, Ferreira AC, Pieper DH, et al. (2003) A novel pathway for mineralization of the thiocarbamate herbicide molinate by a defined bacterial mixed culture. Environ Microbiol 5: 944-953.

64. Mays C, Benfenati E, Pardoe S (2012) Use and perceived benefits and barriers of QSAR models for REACH: findings from a questionnaire to stakeholders. Chem Cent J 6: 159

65. Vedani A, Smiesko M, Spreafico M, Peristera O, Dobler M (2009) VirtualToxLab - in silico prediction of the toxic (endocrine-disrupting) potential of drugs, chemicals and natural products. Two years and 2,000 compounds of experience: a progress report. ALTEX 26: 167-176.

66. Kinsner-Ovaskainen A, Rzepka R, Rudowski R, Coecke S, Cole T, et al. (2009) Acutoxbase, an innovative database for in vitro acute toxicity studies. Toxicol In Vitro 23: 476-485

67. Ellis LB, Hershberger CD, Wackett LP (2000) The University of Minnesota Biocatalysis/Biodegradation database: microorganisms, genomics and prediction. Nucleic Acids Res 28: 377-379.

68. Ellis LB, Hershberger CD, Wackett LP (1999) The University of Minnesota Biocatalysis/Biodegradation Database: specialized metabolism for functional genomics. Nucleic Acids Res 27: 373-376.

69. Ellis LB, Hershberger CD, Bryan EM, Wackett LP (2001) The University of Minnesota Biocatalysis/Biodegradation Database: emphasizing enzymes. Nucleic Acids Res 29: 340-343.

70. Jaimini D, Shabnam AA, Sarkar C (2012) In-Silico Feasibility of Nove Biodegradation Pathways For1-Naphthyl Methylcarbamate. AmericanEurasian Journal of Toxicological Sciences 4: 89-93.

71. Kanehisa M, Goto S, Kawashima S, Nakaya A (2002) The KEGG databases at GenomeNet. Nucleic Acids Res 30: 42-46.

72. HarshaRani GV, Vayttaden SJ, Bhalla US (2005) Electronic data sources for kinetic models of cell signaling. J Biochem 137: 653-657.

73. Selkov E Jr, Grechkin Y, Mikhailova N, Selkov E (1998) MPW: the Metabolic Pathways Database. Nucleic Acids Res 26: 43-45.

74. Caspi R, Altman T, Dale JM, Dreher K, Fulcher CA, et al. (2010) The MetaCyc database of metabolic pathways and enzymes and the BioCyc collection of pathway/genome databases. Nucleic Acids Res 38: D473-D479.

75. http://www.icgeb.res.in/whotdr/cd1/PreCourseReading/NAR_DB2003/www3 oup.co.uk/nar/database/summary/115.html

76. Azzi A (2005) IUBMB Publications: An Overview. IUBMB Life 57: 249-250

77. O'Boyle NM (2012) Towards a Universal SMILES representation - A standard method to generate canonical SMILES based on the InChl. J Cheminform 4 : 22.

78. Reena M, Majhi C, Arya AK, Kumar R, Kumar A (2012) BioRadBase- A Database for Bioremediation of Radioactive waste. 11: 8718-8721.

79. Estimation Program Interface (EPI) Suite (2012) Environmental Protection Agency USA. 